\title{
Analisis Sifat Lasing Bahan Optical Amplifier untuk Sistem Komunikasi Optik Menggunakan Aplikasi berbasis MATLAB
}

\author{
Rudi Susanto ${ }^{1}$, Herliyani Hasanah ${ }^{2}$ \\ ${ }^{1,2}$ Program Studi Teknik Informatika, STMIK Duta Bangsa Surakarta \\ Email: rudist87@gmail ${ }^{1}$; herlydb@gmail.com²
}

Received August 9, 2017; Revised August 16, 2017; Accepted September 11, 2017

\begin{abstract}
Abstrak
Artikel ini berisi tahapan pembuatan aplikasi dengan GUI Matlab yang digunakan untuk menganalis sifat lasing kaca tellurite yang didadah ion erbium dengan teori Judd Ofelt. Tahapan pembuatan aplikasi terdiri dari 1) analisis kebutuhan fungsional, 2) melakukan kajian formulasi model matematis judd ofelt, 3) membuat aplikasi perhitungan parameter judd ofelt dengan Matlab dan 4) Pengujian. Hasil pengujian menunjukkan rata rata error terbesar adalah 5,79\% pada komposisi $\mathrm{x}=1,0$ sedangkan rata rata error terkecil adalah $0,17 \%$ dari hasil ini aplikasi yang dibuat dapat digunakan untuk menganalis sifat lasing. Berdasarkan analisis parameter Judd Ofelt memiliki trend $\Omega_{2}>\Omega_{6}>\Omega_{4}$ yang bersesuaian dengan komposisi lain yaitu TBZNbEr10, SALSFEr, LBTAFEr, TZN dan PKBAEr. Berdasarkan hal tersebut, kaca memiliki potensi untuk dikembangkan sebagai penguat optik dalam sistem komunikasi optik .
\end{abstract}

Kata kunci: Aplikasi, Matlab, Judd Offelt

\section{Analysis of the Laser Properties of Optical Amplifier Materials for Optical Communication Systems Using MATLAB-based Applications}

\begin{abstract}
This article contains the stages of making an application with a GUI Matlab that is used to analyze the lasing properties of tellurite glass doped by erbium ions with Judd Ofelt theory. The stages of making the application consist of 1) functional requirement analysis, 2) conducting the study of mathematical model formulation Judd Ofelt, 3) making application of Judd Ofelt parameter calculation with Matlab and 4) Testing. Test results showed the largest mean error was $5.79 \%$ in the composition $x=1.0$ while the smallest average error is $0.17 \%$ of the results of this application made can be used to analyze the lasing properties. Based on Judd Ofelt parameter analysis has a trend $\Omega 2>$ $\Omega 6>\Omega 4$ which corresponds to other compositions like TBZNbEr10, SALSFEr, LBTAFEr, TZN and PKBAEr. Based on this, glass has the potential to be developed as an optical amplifier in optical communication system
\end{abstract}

Keywords: Applications, Matlab, Judd Offelt

DOI : 10.25273/jpfk.v3i2.1524

\section{PENDAHULUAN}

Pada sistem komunikasi optik jarak transmisi dibatasi oleh adanya rugi-rugi transmisi, yang disebabkan oleh kehilangan daya karena faktor dispersi dan losses. Untuk itu, teknologi penguat optik mempunyai peranan penting dalam sistem komunikasi optik untuk khususnya dalam transmisi jarak jauh. Penguat optik yang bekerja pada panjang gelombang $1500 \mathrm{~nm}$ telah sukses ditemukan yaitu EDFA (Erbium Doped Fibre Amplifier). EDFA merupakan salah satu jenis dari penguat optik, dengan menggunakan EDFA akan diperoleh pembangkitan sinyal dengan faktor penguatan yang lebih besar dan dapat membawa data dengan kecepatan bit yang lebih tinggi 
dibanding penguat elektronik (Baharuddin, 2008)

Parameter utama dalam mendesain EDFA adalah bahan serat optik, karakteristik serat waveguide, profil konsentrasi ion erbium (Samijayani dkk, 2008). Erbium merupakan Ion tanah jarang dapat dengan mudah bergabung dalam beberapa material host kaca seperti silika, borat, pospat, germanium dan tellurite. Kaca berbasis tellurite banyak digunakan sebagai bahan utama karena mampu menghasilkan sifat optik dan dielektrik yang sangat baik. Telah diketahui bahwa kaca berbasis tellurite memiliki karakteristik untuk dijadikan kaca berkualitas tinggi, pita transmisi yang lebar, saklar optik yang cepat, sifat optik linier dan nonlinier yang sangat baik, dan serat optik yang luar biasa untuk sistem komunikasi optik (Noorazlan, 2015).

Kaca berbahan utama tellurite telah dibuat dengan komposisi 55TeO2-2Bi2O3-(43-x)ZnOxEr2O3 dengan nilai $x$ adalah 0,$5 ; 1,0 ; 1,5 ; 2,0 ; 2,5$ dan 3,0 (Susanto, 2014). Diperlukan karakterisasi dan analisis untuk mengetahui kualitas kaca yang telah dihasilkan. Beberapa karakterisasi dilakukan untuk mengetahui sifat fisik dan sifat optik. Sifat fisik seperti indeks kerapatan sedangkan sifat optik yang diukur diantaranya adalah reflektansi, indeks bias dan absorbansi. Karakterisasi reflektansi dan indeks bias menggunakan metode sudut Brewster.
Karakterisasi absorbansi dilakukan dengan spektrofotometer UV/Vis pada rentang panjang gelombang $400 \mathrm{~nm}$ sampai $1100 \mathrm{~nm}$ untuk mengetahui serapan optis kaca tersebut. Untuk analisis mengunakan teori Judd-Ofelt yang sangat penting untuk memperkirakan luminescence dan efisiensi bahan laser (Noorazlan, 2015) (Marzuki, 2007).

Teori Judd Ofelt digunakan untuk menghitung probabilitas transisi radiatif dan radiatife lifetime suatu keadaan tereksitasi, serta cross section emisi terangsang dari ion tanah jarang (Sazali et al. 2014). Proses perhitungan dalam menganalis dapat dilakukan dengan manual dengan bantuan excel atapun dengan mengembangkan aplikasi (Yuliastuti dkk, 2014) Dalam artikel ini disajikan analisis Judd Ofelt dengan aplikasi yang dikembangkan berbasis GUI Matlab.

\section{METODE}

Tujuan penelitian ini adalah menganalis komposisi $\quad 55 \mathrm{TeO}_{2}-2 \mathrm{Bi}_{2} \mathrm{O}_{3}-(43-\mathrm{x}) \mathrm{ZnO}-\mathrm{xEr}_{2} \mathrm{O}_{3}$ dimana $(x=0,5 ; 1,0 ; 1,5 ; 2,0 ; 2,5 ; 3,0)$. Analisis dilakukan untuk memperolah informasi mengenai parameter-parameter yang bertanggung jawab terhadap kualitas EDFA sebagai aplikasi penguat optik. Teori yang digunakan dalam menganalisis mengunakan standar Judd Ofelt.

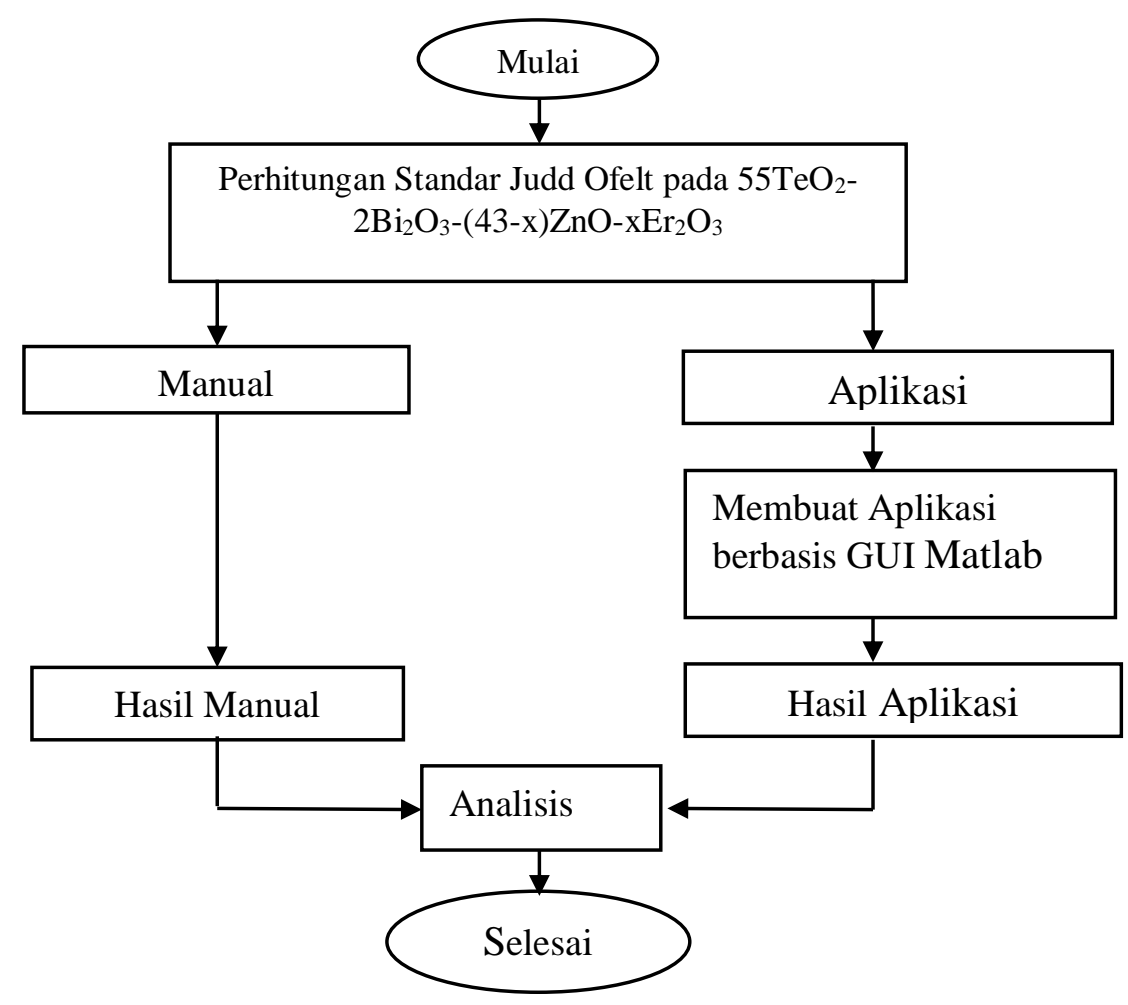

Gambar 1. Diagram alir penelitian 
Diagram alir penelitian disajikan dalam Gambar 1. Perhitungan Manual mengunakan bantuan software excel, Perhitungan aplikasi dibangun dengan software Matlab R2009a. Tahapan pembuatan aplikasi dibagi menjadi empat tahap pelaksanaan yaitu 1) analisis kebutuhan fungsional, 2) melakukan kajian formulasi model matematis judd ofelt, 3) membuat aplikasi perhitungan parameter judd ofelt dengan Matlab dan 4) Melakukan pengujian.

Kegiatan Pertama meliputi analisis kebutuhan input dan output aplikasi. Kegiatan kedua ditujukan untuk mengkaji formulasi model matematis yang akan digunakan dalam pembuatan aplikasi mengunakan GUI matlab. Model matematis yang akan digunakan dalam penelitian ini akan ditentukan dengan metode Judd Offelt. Dari tahapan ini dihasilkan script sesuai dengan bahasa pemrograman matlab. Pada tahap ketiga, penelitian dilakukan untuk pembuatan aplikasi berbasis GUI Matlab. Input aplikasi berupa nilai Indeks bias, tebal kaca, jumlah ion erbium, panjang gelombang dan area berdasarkan hasil karakterisasi serta Nilai U2, U4, U6, di peroleh dari Tabel Karnal. Tahap keempat adalah pengujian aplikasi dilakukan dengan cara membandingkan hasil aplikasi dengan hasil perhitungan manual untuk melihat kesesuain hasil.

Analisis sifat lasing dari kaca yang parameter judd ofelt nya telah didapatkan dari hasil aplikasi dan manual. Dari tahap ini dapat diketahui kualitas sifat lasing dari sampel dengan komposisi 55TeO2-2Bi2O3-(43-x)ZnO$\mathrm{xEr} 2 \mathrm{O} 3$

\section{HASIL DAN PEMBAHASAN}

Analisis kebutuhan fungsional aplikasi didasarkan pada standar Judd Ofelt dan hasil karaterisasi kaca pada komposisi 55TeO22Bi2O3-(43-x)ZnO-xEr2O3. Gambar 2 merupakan hasil karakteristik UV/Vis yang menunjukkan terdapat delapan puncak yaitu sekitar panjang gelombang 408, 451, 489, 521, $544,653,799,980 \mathrm{~nm}$ yang sama dengan level energi 4H9/2, 4F5/2, 4F7/2 , 4H11/2, 4S3/2, 4F9/2, 4I9/2, dan 4I11/2. Hasil temuan puncak puncak tersebut sama dengan penelitian lain (Sazali et al, 2014) (Pradeesh et al, 2008) yang akan dijadikan input aplikasi. Tabel 1 menunjukkan panjang gelombang setiap komposisi yang didapatkan dari Gambar 1 dengan pengolahan menggunakan software origin.

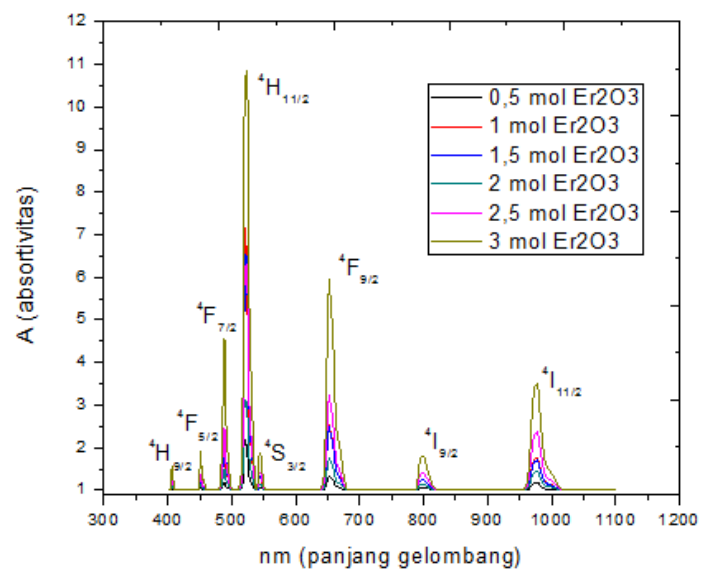

Gambar 2. Hasil karakteristik UV/Vis pada komposisi $55 \mathrm{TeO}_{2}-2 \mathrm{Bi}_{2} \mathrm{O}_{3}-(43-\mathrm{x}) \mathrm{ZnO}-\mathrm{xEr}_{2} \mathrm{O}_{3}$

Tabel 1. Panjang gelombang setiap komposisi (nm)

\begin{tabular}{|c|c|c|c|c|c|c|}
\hline \multirow[t]{2}{*}{ Tingkat Energi } & \multicolumn{6}{|c|}{$\begin{array}{c}\text { Panjang gelombang komposisi } 5_{5 \mathrm{TeO}_{2}-2 \mathrm{Bi}_{2} \mathrm{O}_{3}-(43-} \\
\text { x) } \mathrm{ZnO}-\mathrm{xEr}_{2} \mathrm{O}_{3} \\
\end{array}$} \\
\hline & $x=0,5$ & $x=1,0$ & $x=1,5$ & $x=2,0$ & $x=2,5$ & $x=3,0$ \\
\hline $4 \mathrm{I} 11 / 2$ & 976.9 & 977.7 & 977.9 & 977.6 & 977.5 & 977.7 \\
\hline $4 \mathrm{I} 9 / 2$ & 799.2 & 798.6 & 798.8 & 798.6 & 798.9 & 798.5 \\
\hline $4 \mathrm{~F} 9 / 2$ & 652.7 & 652.7 & 652.7 & 652.5 & 652.7 & 652.7 \\
\hline $4 \mathrm{~S} 3 / 2$ & 543.7 & 543.8 & 544.2 & 544.1 & 543.9 & 543.9 \\
\hline $4 \mathrm{H} 11 / 2$ & 521.1 & 521.1 & 522 & 521.6 & 522.6 & 522.7 \\
\hline $4 \mathrm{~F} 7 / 2$ & 488.6 & 488.6 & 489.2 & 488.6 & 488.6 & 488.6 \\
\hline $4 \mathrm{~F} 5 / 2$ & 451 & 451 & 451.7 & 451.1 & 451.1 & 451.2 \\
\hline $4 \mathrm{H} 9 / 2$ & 407.2 & 407.2 & 407.6 & 407.1 & 407.1 & 407.1 \\
\hline
\end{tabular}


Puncak serapan transisi ${ }^{4} \mathrm{I}_{15 / 2} \rightarrow{ }^{2} \mathrm{H}_{11 / 2}$ menunjukkan intensitas tertinggi di antara semua sampel kaca. Selanjutnya, peningkatan konsentrasi ion $\mathrm{Er}^{3+}$ meningkatkan intensitas absorbansi disertai pergeseran puncak menuju panjang gelombang yang lebih pendek yang dianggap berasal dari penataan ulang struktur pada kaca (Sazali et al, 2014).

Studi terperinci mengenai parameter Judd Ofelt $\left(\Omega_{2,4,6}\right)$ penting untuk menyelidiki struktur lokal, ikatan di sekitar dan sifat transisi ion tanah jarang. Berdasarkan (Marzuki, 2007) (Sardar et al, 2003) kekuatan osilator eksperimental $\left(f_{\text {meas }}\right)$ untuk transisi yang berbeda diperoleh dari spektrum penyerapan dengan menggunakan persamaan 1 .

$f_{\text {meas }}=\frac{3 \operatorname{ch}(2 J+1)}{8 \pi^{3} e^{2} N} \frac{9 n}{\left(n^{2}+2\right)^{2}} \frac{23}{\bar{\lambda}} \int_{J \rightarrow f^{\prime}} O D(\lambda) d \lambda(1)$
Dimana $I$ dan $I$ adalah merupakan momentum sudut total bilangan kuantum dari keadaan awal dan akhir, $\bar{\lambda}$ adalah panjang gelombang rata-rata pita absorpsi, $n$ adalah indeks bias kaca pada $\bar{\lambda}$, $c$ adalah kecepatan cahaya, $e$ adalah muatan elektron, $N$ adalah konsentrasi ion $\mathrm{Er}^{3+}, \quad h$ adalah konstanta Plank, $O D$ adalah densitas optik yang ditentukan dengan persamaan 2 (Marzuki, 2007) dengan $I_{b}(\lambda)$ dan $I_{s}(\lambda)$ adalah intensitas absorpsi. Data Nilai indeks bias, konsentrasi ion $\mathrm{Er}^{3+}$ dan Tebal bahan sebagai input aplikasi sesuai persamaan 1 disajikan dalam Tabel 2.

$O D(\lambda)=\log \frac{I_{b}(\lambda)}{I_{S}(\lambda)}$

Tabel 2. Nilai indeks bias dan konsentrasi ion Er3+

\begin{tabular}{lccc}
\hline \multicolumn{1}{c}{ Komposisi } & Indeks bias & Jumlah Ion & Tebal $(\mathbf{c m})$ \\
\hline $0,5 \mathrm{~mol} \mathrm{Er} 2 \mathrm{o} 3$ & 1.9013 & $3.60 \mathrm{E}+20$ & 0.189 \\
\hline $1 \mathrm{~mol} \mathrm{Er} 2 \mathrm{o} 3$ & 1.9240 & $7.13 \mathrm{E}+20$ & 0.191 \\
\hline $1,5 \mathrm{~mol} \mathrm{Er} 2 \mathrm{o} 3$ & 1.9500 & $1.06 \mathrm{E}+21$ & 0.191 \\
\hline $2 \mathrm{~mol} \mathrm{Er} 2 \mathrm{o} 3$ & 1.9600 & $1.39 \mathrm{E}+21$ & 0.189 \\
\hline $2,5 \mathrm{~mol} \mathrm{Er} 2 \mathrm{o} 3$ & 1.9833 & $1.72 \mathrm{E}+21$ & 0.186 \\
\hline $3 \mathrm{~mol} \mathrm{Er2o3}$ & 1.9533 & $2.05 \mathrm{E}+21$ & 0.192 \\
\hline
\end{tabular}

Tabel 3. Nilai densitas optik

\begin{tabular}{|c|c|c|c|c|c|c|}
\hline \multirow{2}{*}{$\begin{array}{l}\text { Tingkat } \\
\text { Energi }\end{array}$} & \multicolumn{6}{|c|}{ Densitas optik komposisi $55 \mathrm{TeO}_{2}-2 \mathrm{Bi}_{2} \mathrm{O}_{3}-(43-\mathrm{x}) \mathrm{ZnO}-\mathrm{xEr}_{2} \mathrm{O}_{3}$} \\
\hline & $\mathbf{x}=\mathbf{0 , 5}$ & $\mathbf{x}=\mathbf{1 , 0}$ & $x=1,5$ & $\mathbf{x}=\mathbf{2 , 0}$ & $x=2,5$ & $x=3,0$ \\
\hline $4 \mathrm{I} 11 / 2$ & 3.19333 & 15.77082 & 14.67048 & 9.37499 & 28.97796 & 53.26056 \\
\hline $4 \mathrm{I} 9 / 2$ & 1.05912 & 4.10818 & 3.93574 & 2.25872 & 6.9068 & 13.51777 \\
\hline $4 \mathrm{~F} 9 / 2$ & 4.57985 & 22.142 & 21.01057 & 10.77754 & 32.48131 & 72.50492 \\
\hline $4 \mathrm{~S} 3 / 2$ & 0.40168 & 2.12545 & 2.03987 & 0.97692 & 2.71108 & 5.83771 \\
\hline $4 \mathrm{H} 11 / 2$ & 9.71541 & 50.86913 & 48.36531 & 19.96612 & 52.28317 & 102.7366 \\
\hline $4 \mathrm{~F} 7 / 2$ & 1.28758 & 7.72834 & 7.87387 & 3.32134 & 9.51408 & 23.34227 \\
\hline $4 \mathrm{~F} 5 / 2$ & 0.15036 & 1.27276 & 1.25392 & 0.56374 & 1.55258 & 3.75815 \\
\hline $4 \mathrm{H} 9 / 2$ & 0.12869 & 0.60545 & 0.61743 & 0.37559 & 0.89564 & 1.88496 \\
\hline
\end{tabular}

Kekuatan osilator yang dihitung $\left(f_{\text {calc }}\right)$ persamaan 3 ditentukan oleh isolasi kedua dipol listrik dan kontribusi magnetik-dipol dari hasil $f_{\text {meas. }}$.

$f_{\text {calc }}\left(J \rightarrow J^{\mathrm{r}}\right)=$
$\sum_{t=2,4,6} \Omega_{\mathrm{t}}\left|\left\langle(S, L) J\left\|U^{(t)}\right\|\left(S^{\sigma}, L^{\sigma}\right) J\right)\right|^{2}$

(3)
Dimana $[(S, L) J\rangle$ adalah transisi dari keadaan awal dan keadaan akhir $\left.\|\left(S^{*}, L^{*}\right) J^{*}\right)$ sedangkan nilai $U^{(t)}$ adalah elemen matriks kuadrat dikurangi dari operator tensor unit. Nilai $\Omega_{\mathrm{t}}$ (Carnall et al .1978) disajikan dalam Tabel 4. 
Jurnal Pendidikan Fisika dan Keilmuan (JPFK) Vol 3 No 2 September 2017, hal 7o-77

Avaliable online at: http://e-journal.unipma.ac.id/index.php/JPFK

Print ISSN: 2442-8868, Online ISSN: 2442-904x

Tabel 4. Nilai $U^{(t)}$

\begin{tabular}{lrrr}
\hline $\begin{array}{c}\text { Tingkat } \\
\text { Energi }\end{array}$ & {$[\mathbf{U}(\mathbf{2})]^{\wedge} \mathbf{2}$} & {$[\mathbf{U}(\mathbf{4})]^{\wedge} \mathbf{2}$} & {$[\mathbf{U}(\mathbf{6})]^{\wedge} \mathbf{2}$} \\
\hline $4 \mathrm{I} 11 / 2$ & 0.0463 & 0.0017 & 0.2426 \\
\hline $4 \mathrm{I} 9 / 2$ & 0 & 0.1201 & 0.0969 \\
\hline $4 \mathrm{~F} 9 / 2$ & 0 & 0.0867 & 0.0142 \\
\hline $4 \mathrm{~S} 3 / 2$ & 0 & 0 & 0.0035 \\
\hline $4 \mathrm{H} 11 / 2$ & 0.101 & 0 & 1.1445 \\
\hline $4 \mathrm{~F} 7 / 2$ & 0 & 0.1465 & 0.6272 \\
\hline $4 \mathrm{~F} 5 / 2$ & 0 & 0 & 0.2221 \\
\hline $4 \mathrm{H} 9 / 2$ & 0 & 0.7139 & 0.0822 \\
\hline
\end{tabular}

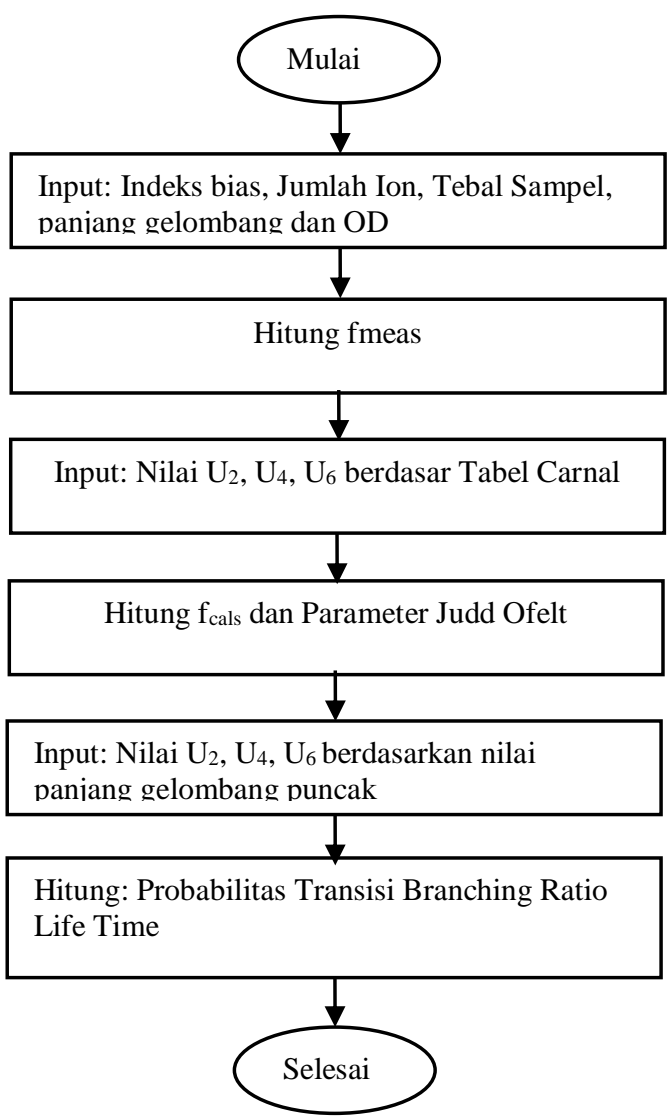

Gambar 3. Diagram Alir Aplikasi

Berdasarkan analisis tersebut di atas selanjutnya dibuat diagram alir aplikasi, seperti disajikan dalam Gambar 3. Dalam diagram alir tersebut input aplikasi sesuaikan dengan formula 1 dan 3 yaitu indeks bias, tebal kaca, jumlah ion, panjang gelombang, densitas optik dan U2, U4, U6. Sedangkan output aplikasi adalah $f_{\text {meas }}$, $f_{\text {cale }}$, Parameter Judd Ofelt.
Gambar 4 merupakan hasil aplikasi yang dibuat berdasarkan diagram alir, aplikasi dibuat dengan GUI Matlab R2009a. Berikut adalah potongan listing code untuk $f_{\text {meas }}, f_{\text {calc }}$, dan Parameter Judd Ofelt.

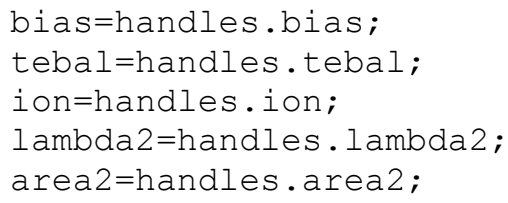


Jurnal Pendidikan Fisika dan Keilmuan (JPFK) Vol 3 No 2 September 2017, hal 7o-77

Avaliable online at: http://e-journal.unipma.ac.id/index.php/JPFK

Print ISSN: 2442-8868, Online ISSN: 2442-904x
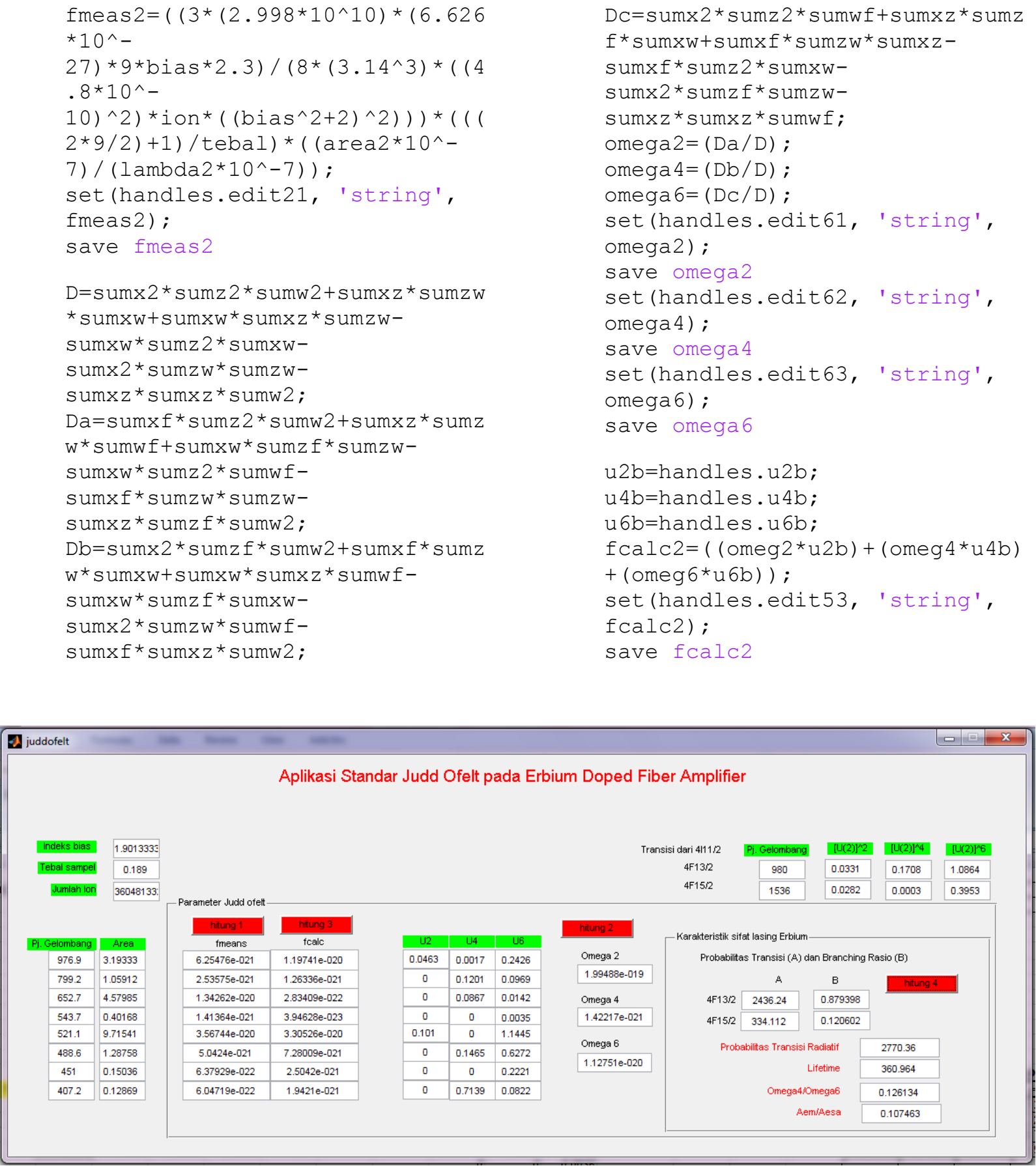

Gambar 4. Hasil aplikasi

Tabel 5. Data hasil perhitungan $\mathrm{f}_{\text {meas }}$ manual dan aplikasi $\left(10^{-2} \mathrm{~cm}\right)$

\begin{tabular}{lccccccccc}
\hline Tingkat & \multicolumn{3}{c}{$\mathbf{x = 0 , 5}$} & \multicolumn{3}{c}{$\mathbf{x = 1 , 0}$} & \multicolumn{3}{c}{$\mathbf{x = 1 , 5}$} \\
\cline { 2 - 11 } Energi & Manual & Aplikasi & error & Manual & Aplikasi & error & Manual & Aplikasi & error \\
\hline $4 \mathrm{I} 11 / 2$ & 0.630 & 0.630 & 0.000 & 1.520 & 1.520 & 0.000 & 0.940 & 0.928 & 0.012 \\
\hline $4 \mathrm{I} 9 / 2$ & 0.250 & 0.254 & 0.004 & 0.480 & 0.025 & 0.455 & 0.310 & 0.305 & 0.005 \\
\hline $4 \mathrm{~F} 9 / 2$ & 1.340 & 1.340 & 0.000 & 3.190 & 3.190 & 0.000 & 2.020 & 1.990 & 0.030 \\
\hline $4 \mathrm{~S} 3 / 2$ & 0.140 & 0.141 & 0.001 & 0.370 & 0.367 & 0.003 & 0.230 & 0.232 & 0.002 \\
\hline
\end{tabular}


Jurnal Pendidikan Fisika dan Keilmuan (JPFK) Vol 3 No 2 September 2017, hal 7o-77

Avaliable online at: http://e-journal.unipma.ac.id/index.php/JPFK

Print ISSN: 2442-8868, Online ISSN: 2442-904x

\begin{tabular}{|c|c|c|c|c|c|c|c|c|c|}
\hline $4 \mathrm{H} 11 / 2$ & 3.570 & 3.570 & 0.000 & 9.170 & 9.170 & 0.000 & 5.800 & 5.730 & 0.070 \\
\hline $4 \mathrm{~F} 7 / 2$ & 0.500 & 0.504 & 0.004 & 1.490 & 1.490 & 0.000 & 1.000 & 0.995 & 0.005 \\
\hline 4F5/2 & 0.060 & 0.064 & 0.004 & 0.260 & 0.265 & 0.005 & 0.170 & 0.172 & 0.002 \\
\hline $4 \mathrm{H} 9 / 2$ & 0.060 & 0.061 & 0.001 & 0.140 & 0.140 & 0.000 & 0.090 & 0.094 & 0.004 \\
\hline \multicolumn{3}{|c|}{ Error rata rata } & 0.0017 & \multicolumn{2}{|c|}{ Error rata rata } & 0.0579 & \multicolumn{2}{|c|}{ Error rata rata } & 0.0162 \\
\hline \multirow{2}{*}{$\begin{array}{l}\text { Tingkat } \\
\text { Energi }\end{array}$} & \multicolumn{3}{|c|}{$x=2,0$} & \multicolumn{3}{|c|}{$x=2,5$} & \multicolumn{3}{|c|}{$x=3,0$} \\
\hline & Manual & Aplikasi & error & Manual & Aplikasi & error & Manual & Aplikasi & error \\
\hline $4 \mathrm{I} 11 / 2$ & 0.250 & 0.453 & 0.203 & 1.130 & 1.130 & 0.000 & 1.730 & 1.730 & 0.000 \\
\hline $4 \mathrm{I} 9 / 2$ & 0.130 & 0.134 & 0.004 & 0.330 & 0.329 & 0.001 & 0.540 & 0.537 & 0.003 \\
\hline $4 \mathrm{~F} 9 / 2$ & 0.780 & 0.781 & 0.001 & 1.890 & 1.890 & 0.000 & 3.530 & 3.520 & 0.010 \\
\hline $4 \mathrm{~S} 3 / 2$ & 0.080 & 0.085 & 0.005 & 0.190 & 0.190 & 0.000 & 0.340 & 0.340 & 0.000 \\
\hline $4 \mathrm{H} 11 / 2$ & 1.800 & 1.810 & 0.010 & 3.800 & 3.810 & 0.010 & 6.240 & 6.240 & 0.000 \\
\hline $4 \mathrm{~F} 7 / 2$ & 0.320 & 0.321 & 0.001 & 0.740 & 0.741 & 0.001 & 1.520 & 1.520 & 0.000 \\
\hline $4 \mathrm{~F} 5 / 2$ & 0.060 & 0.059 & 0.001 & 0.130 & 0.131 & 0.001 & 0.260 & 0.264 & 0.004 \\
\hline $4 \mathrm{H} 9 / 2$ & 0.040 & 0.044 & 0.004 & 0.080 & 0.084 & 0.004 & 0.150 & 0.147 & 0.003 \\
\hline \multicolumn{3}{|c|}{ Error rata rata } & 0.0286 & Error & ta rata & 0.0021 & Error rat & ata & 0.0025 \\
\hline
\end{tabular}

Hasil perbandingan aplikasi dan manual disajikan dalam Tabel 5. Dari hasil perbandingan rata rata error terbesar adalah 5,79\% pada komposisi $\mathrm{x}=1,0$ sedangkan rata rata error terkecil adalah $0,17 \%$ dari hasil ini aplikasi yang dibuat dapat digunakan untuk menganalis sifat lasing.

Hasil perhitungan aplikasi terkait dengan parameter Judd Ofelt di sajikan dalam Tabel 6. Ilustrasi nilai $\Omega_{2}, \Omega_{4}, \Omega_{6}$ disajikan dalam Gambar
5. Trend nilai hasil perhitungan menunjukkan $\Omega_{2}>\Omega_{6}>\Omega_{4}$, nilai hasil perhitungan ini sesuai dengan (Seshadri et al, 2014) pada kaca TBZNbEr10, SALSFEr, LBTAFEr, TZN dan PKBAEr. Kesesuain hasil dan trend nilai paramater Judd Ofelt ini menunjukkan bahwa sampel memiliki potensi untuk dikembangkan sebagai penguat optik dalam sistem komunikasi optik.

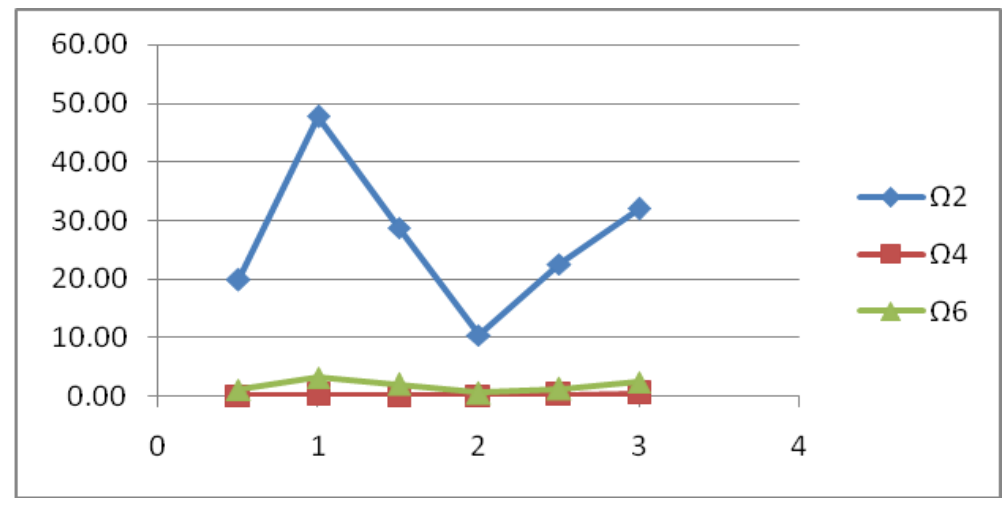

Gambar 5. Grafik nilai $\Omega_{2}, \Omega_{4}, \Omega_{6}$

Tabel 6. Hasil perhitunga parameter Judd Ofelt dengan aplikasi (x 10-20 cm2)

\begin{tabular}{lrrr}
\hline $\mathbf{E r 2 O 3}(\mathbf{m o l} \%)$ & $\Omega_{2}$ & $\Omega_{4}$ & \multicolumn{2}{c}{$\Omega_{6}$} \\
\hline $\mathbf{x = 0 , 5}$ & 26.90 & 0.26 & 0.74 \\
\hline $\mathbf{x = 1 , 0}$ & 65.80 & 0.52 & 2.20 \\
\hline $\mathbf{x = 1 , 5}$ & 40.50 & 0.33 & 1.49 \\
\hline $\mathbf{x = \mathbf { 2 , 0 }}$ & 12.40 & 0.15 & 0.47 \\
\hline $\mathbf{x = 1 , 5}$ & 25.10 & 0.34 & 1.09 \\
\hline $\mathbf{x = 3 , 0}$ & 36.30 & 0.59 & 2.24 \\
\hline
\end{tabular}




\section{KESIMPULAN}

Hasil perhitungan aplikasi GUI Matlab memiliki error rata rata terbesar $5,79 \%$ terhadap perhitungan manual. Berdasarkan analisis parameter Judd Ofelt meliki trend $\Omega_{2}>\Omega_{6}>\Omega_{4}$ yang bersesuaian dengan komposisi lain yaitu TBZNbEr10, SALSFEr, LBTAFEr, TZN dan PKBAEr. Berdasarkan hal tersebut, kaca dengan komposisi 55TeO22Bi2O3-(43-x) ZnO-xEr2O3 dimana (x=0,5; 1,0; $1,5 ; 2,0 ; 2,5 ; 3,0)$ memiliki potensi untuk dikembangankan sebagai penguat optik dalam sistem komunikasi optik.

\section{UCAPAN TERIMAKASIH}

Penulis mengucapkan terima kasih kepada Direktorat Riset dan Pengabdian Masyarakat Kementerian Riset, Teknologi dan Pendidikan Tinggi yang telah mendanai penelitian ini.

\section{DAFTAR PUSTAKA}

Baharuddin. (20080. Evaluasi Penerapan Penguat Optik EDFA - Raman Pada Sistem Komunikasi Fiber Optik. Jurnal Teknika No. 29 Vol. 2 Thn. XV April 2008 ISSN: 08548471

Carnall et al. (1978). Energy level structure and transition probabilities in the spectra of the trivalent lanthanides in LaF3. Argonne National Lab., IL

Marzuki, A. (2009). Laser analysis of Nd3+ ions in fluoroaluminate glasses. Jurnal Matematika \& Sains, 12(1), 32-37.

Noorazlan, A. M. et al. (2015). Green Emission of Tellurite Based Glass Containing Erbium Oxide Nanoparticles. Journal of Nanomaterials Volume 2015
Pradeesh, K., Oton, C. J., Agotiya, V. K., Raghavendra, M., \& Prakash, G. V. (2008). Optical properties of Er 3+ doped alkali chlorophosphate glasses for optical amplifiers. Optical materials, 31(2), 155160.

Samijayani, O. N., \& Syahriar, A. (2008). Aplikasi In-line Amplifier EDFA Pada Sistem Transmisi Panjang Gelombang Tunggal dan Transmisi Berbasis WDM. Konferensi dan Temu Nasional Teknologi Informasi dan Komunikasi untuk Indonesia, 21-23.

Sardar, D. K., Gruber, J. B., Zandi, B., Hutchinson, J. A., \& Trussell, C. W. (2003). Judd-Ofelt analysis of the Er 3+(4f 11) absorption intensities in phosphate glass: $\mathrm{Er} 3+, \mathrm{Yb} 3+$. Journal of applied physics, 93(4), 2041-2046.

Sazali, E. S., Sahar, R., Ghoshal, S. K., Rohani, S., \& Arifin, R. (2014). JUDD-OFELT INTENSITY PARAMETERS OF ERBIUM DOPED LEAD TELLURITE GLASS. Journal of Non-Oxide Glasses Vol, 6(4), 61-67.

Seshadri et al. 2014. Optical characterization, infrared emission and visible up-conversion in Er3+ doped tellurite glasses. Journal of Non-Crystalline Solids 402 (2014) 141-148

Susanto, R., \& Marzuki, A. (2014). Pengaruh Konsentrasi Ion Erbium pada Sifat Fisik dan Optik Kaca Telurium Oxide sebagai Bahan Penguat Optik. Jurnal Materi dan Pembelajaran Fisika, 4(1).

Yuliastuti, I., \& Rahmasari, L. (2015). Pembuatan Aplikasi Program Matlab untuk Menganalisa Sifat Lasing Kaca TZBN Yang Didadah Ion Nd3+ sebagai Bahan Material Host Laser (Halaman 97 sd 102). Jurnal Fisika Indonesia, 18(54). 